\title{
Integrasi Literasi Matematika Berdasarkan Self-Efficacy Pada Discovery Learning-Hots
}

\author{
Wihdati Martalyna
}

SMAN 1 Slawi

\begin{abstract}
Mathematical literacy is mathematical thinking to examine and analyze a phenomenon, and solve problems for many scientific disciplines. The development of mathematical literacy based on HOTS allows students to ask questions, identify problems, and engage problem solving discussions. Soft skills of self-efficacy belief in self-ability also contributes to the students' problem solving. The purposes of this study were to describe the quality of Discovery Learning-HOTS on mathematical literacy, to describe students' mathematical literacy based on self-efficacy, and to analyze the effect of self-efficacy on mathematical literacy. The research subjects were students of grade X of SMA 1 Slawi Senior High School. The result of this research showed that Discovery Learning-HOTS had positive effect towards students' mathematical literacy. Students with high self-efficacy mastered four aspects of the process in mathematical literacy very well, and mastered the other three aspects well with few mistakes. Students with medium self-efficacy mastered one aspect very well, and the other six aspects well with some mistakes. Furthermore, students with low self-efficacy, mastered five aspects not as well as the medium, and had not been able to master the other two aspects. Self-efficacy had positive effect of $34.6 \%$ towards mathematical literacy in Discovery Learning-HOTS.
\end{abstract}

Keywords: discovery learning-HOTS, mathematical literacy, self-efficacy

\section{Pendahuluan}

Eksistensi matematika memiliki peran penting dan dibutuhkan oleh berbagai sektor kalangan masyarakat untuk memajukan daya pikir manusia. Matematika merupakan salah satu ilmu yang diperoleh siswa melalui pendidikan formal di sekolah. Matematika sekolah merupakan sarana untuk mengembangkan potensi serta hasrat keingintahuan siswa terhadap hal-hal yang berkaitan dengan matematika maupun aplikasinya dalam kehidupan. Junaedi dan Asikin (2012: 115) menerangkan bahwa pembelajaran matematika di sekolah perlu dirancang untuk mendorong siswa memiliki keahlian matematis, seperti pemahaman, komunikasi, koneksi, penalaran dan pemecahan masalah. Berbagai kemahiran tersebut diperlukan siswa supaya dapat memanfaatkan informasi untuk bertahan pada kondisi kehidupan yang selalu berkembang dan kompetitif. Hal tersebut sejalan dengan gagasan mengenai konsep literasi matematika.

Literasi matematika merupakan kemampuan untuk mengidentifikasi peran dan nalar matematika dalam konteks yang bervariasi, dan menyelesaikan masalah matematika nyata secara konstruktif. Menurut lembaga internasional yang melakukan studi literasi matematika dunia, yaitu OECD (2016: 66), definisi literasi matematika dianalisis dalam tiga aspek, yaitu aspek proses, isi, serta konteks. Aspek dalam penelitian ini adalah aspek proses, dimana terdapat tujuh kemampuan yang mendasarinya, yaitu communication, mathematising, representation, reasoning and argument, devising strategies for solving problems, using symbolic, formal and technical language and operation, dan using mathematics tools. 
Retnowati \& Aqiilah (2017: 14) menerangkan bahwa salah satu faktor yang harus dikenali guru terhadap siswa selama proses pembelajaran adalah psikologis siswa. Waluya (2012: 11) juga menyatakan bahwa kesuksesan siswa tidak hanya ditentukan oleh hard skills siswa, namun juga oleh soft skills. Oleh karena itu, soft skills siswa berupa kemampuan untuk memimpin diri dan orang lain juga menentukan keberhasilan siswa dalam memecahkan masalah.

Bandura (1994: 2) menyatakan bahwa self-efficacy diartikan sebagai kepercayaan seseorang mengenai kemampuan dirinya sendiri untuk menghasilkan tingkatan prestasinya.

Self-efficacy siswa semakin mudah dikembangkan apabila guru menggunakan pembelajaran yang mampu menumbuhkan kepercayaan dirinya. Self-efficacy literasi matematika siswa bisa ditingkatkan dengan menggunakan strategi pembelajaran yang membantu siswa untuk membangun tujuan belajarnya, memastikan siswa mampu bekerja keras, dan memberi umpan balik atas respon siswa (Ozgen \& Bindak, 2011: 1088). Pembelajaran perlu memberikan kesempatan kepada siswa dapat mengungkapkan gagasan matematisnya untuk menyelesaikan tugas dan menumbuhkan selfefficacy.

Discovery Learning adalah sebuah pembelajaran dengan strategi pembelajaran terpadu sehingga memungkinkan siswa untuk belajar secara optimal dan menunjang literasi matematika.

Selain pembelajaran aktif dan kreatif, keterampilan pola berpikir siswa juga menentukan keberhasilan siswa dalam pembelajaran, pengembangan literasi dan self-efficacy matematika. Pola berpikir matematis ini terbagi menjadi dua, yaitu berpikir tingkat rendah (low-order thinking) dan berpikir tingkat tinggi (higher order thinking). Rajendran (2008) menyebutkan bahwa higher order thinking didefinisikan sebagai pengembangan level berpikir terhadap tantangan-tantangan baru. Sedangkan, lower order thinking mewakili tingkatan berpikir dalam penerapan rutin, mekanisme, dan penggunaan pikiran yang terbatas.

HOTS dikembangkan dalam pertanyaan-pertanyaan yang didasarkan atas variabel proses berpikir oleh King, Goodson, dan Rohani (1998), yaitu: (1) context, (2) metacognition, (3) procedural knowledge, (4) comprehension, (5) creativity, (6) insight, (7) intelligence, (8) problem solving, dan (9) critical thinking.

Inovasi pembelajaran Discovery Learning-HOTS menginterpretasikan langkah-langkah Discovery Learning serta mengintegrasikan higher order thinking skills dalam setiap pembelajarannya.

Tujuan yang ingin dicapai dalam penelitian ini adalah mendeskripsikan kualitas pembelajaran Discovery Learning-HOTS terhadap literasi matematika siswa, menganalisis dan mendeskripsikan literasi matematika siswa ditinjau dari self-efficacy, dan menganalisis pengaruh self-efficacy terhadap literasi matematika siswa. Kualitas pembelajaran diukur melalui tiga tahap, yaitu tahap perencanaan pembelajaran, tahap pelaksanaan proses pembelajaran, dan tahap penilaian hasil pembelajaran.

\section{Metodologi Penelitian}

Metode penelitian yang digunakan adalah mixed method tipe concurrent embedded design, dimana quasi experiment design digunakan untuk kuantitatif. Penelitian dilaksanakan di SMA Negeri 1 Slawi dengan populasi penelitian adalah siswa kelas $\mathrm{X}$ tahun ajaran $2017 / 2018$. 
Sumber data pada penelitian ini adalah hasil Tes Kemampuan Literasi Matematika (TKLM) siswa, hasil angket self-efficacy, rekam hasil wawancara literasi matematika, serta observasi aktivitas guru selama proses pembelajaran. Skor TKLM sebagai sumber data kuantitatif, sedangkan lembar jawab TKLM, hasil angket selfefficacy, dan hasil wawancara sebagai sumber data kualitatif. Analisis data kuantitatif dilakukan dengan uji normalitas, homogenitas, ketuntasan proporsi, ketuntasan rata-rata, banding proporsi, banding rata-rata, peningkatan self-efficacy, serta regresi. Analisis data kualitatif dilakukan dengan validasi data, pembuatan transkrip data verbal, reduksi data, penyajian data, dan verifikasi data.

\section{Hasil dan Pembahasan}

Pada tahap perencanaan pembelajaran, diperoleh rata-rata skor validasi perangkat pembelajaran adalah 4,51, serta rata-rata skor validasi instrumen pembelajaran adalah 4,63. Berikut adalah rincian skor validasi yang diperoleh.

Tabel 1 Hasil Validasi Perangkat Pembelajaran dan Instrumen Penelitian

\begin{tabular}{|c|c|c|}
\hline $\begin{array}{l}\text { Perangkat } \\
\text { Pembelajaran/ } \\
\text { Instrumen Penelitian }\end{array}$ & $\begin{array}{l}\text { Rata- } \\
\text { Rata } \\
\text { Skor }\end{array}$ & Kategori \\
\hline Silabus & 4.52 & $\mathrm{SB}$ \\
\hline RPP & 4.53 & SB \\
\hline Buku Siswa & 4.53 & $\mathrm{SB}$ \\
\hline LKS & 4.47 & $\mathrm{SB}$ \\
\hline $\begin{array}{l}\text { Angket Self-Efficacy } \\
\text { Siswa }\end{array}$ & 4.75 & SB \\
\hline $\begin{array}{l}\text { Angket Self-Efficacy } \\
\text { Matematika Siswa }\end{array}$ & 4.58 & SB \\
\hline Soal TKLM & 4.5 & SB \\
\hline $\begin{array}{l}\text { Pedoman Wawancara } \\
\text { KLM }\end{array}$ & 4.5 & $\mathrm{SB}$ \\
\hline Observasi & & SB \\
\hline $\begin{array}{l}\text { Keterlaksanaan } \\
\text { Pembelajaran }\end{array}$ & 4.67 & \\
\hline Angket Respon Siswa & 4.75 & SB \\
\hline
\end{tabular}

Ket: SB=Sangat Baik, B=Baik

Hasil perangkat dan instrumen penelitian dalam kategori sangat baik dan layak digunakan. Oleh karena itu, tahap perencanaan pembelajaran Discovery Learning-HOTS dikatakan berkualitas.

Sebelum tahap pelaksanaan pembelajaran, data self-efficacy dikumpulkan untuk digunakan sebagai acuan analisis data penelitian. Hasil persentase siswa dengan selfefficacy tinggi adalah $12,5 \%$, siswa dengan self-efficacy sedang adalah $68.75 \%$, dan siswa dengan selfefficacy rendah adalah $18.75 \%$.

Pada tahap pelaksanaan pembelajaran, kualitas pembelajaran diukur dengan observasi keterlaksanaan pembelajaran dan angket respon siswa terhadap pembelajaran Discovery LearningHOTS. Dari observasi yang telah dilakukan, diperoleh rata-rata skor keterlaksanaan pembelajaran adalah 4,225 atau $84,5 \%$, sehingga pembelajaran yang dilaksanakan dalam kategori sangat baik, atau dikatakan 84,5\% sesuai dengan RPP. Berdasarkan hasil analisis data respon siswa, diperoleh skor rata-rata 2,94 atau $73,36 \%$, sehingga dapat dikatakan bahwa siswa menilai pembelajaran yang dilaksanakan adalah $73,36 \%$ baik. Oleh karena itu, tahap pelaksanaan pembelajaran Discovery Learning-HOTS dikatakan berkualitas.

Proses

mengintegrasikan higher order thinking skills, dimana guru memfasilitasi siswa untuk menjadi problem solver dengan cara memberikan berbagai permasalahan yang memungkinkan siswa untuk berpikir dalam level tinggi. Setiap masalah disajikan dalam bentuk kasus dan memiliki berbagai subpenyelesaian, seperti identifikasi masalah, hipotesis, mencari informasi, ilustrasi, konsep materi, penyelesaian, kesimpulan, dan rangkuman. Berikut 
adalah contoh hasil diskusi siswa pada masalah di lembar kerja.

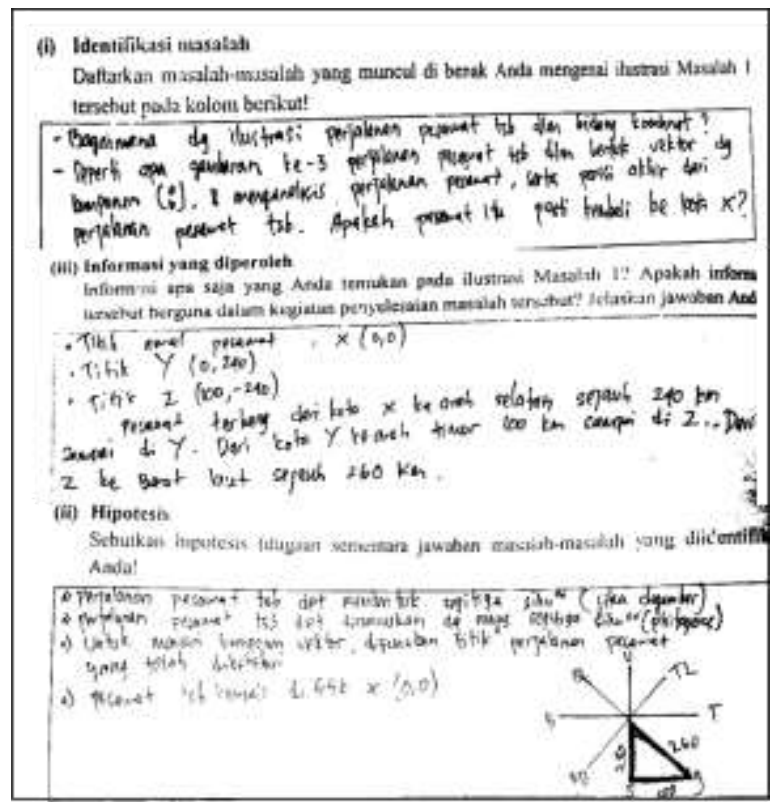

Gambar 1 Contoh Hasil Diskusi Siswa dalam Identifikasi Masalah, Informasi, dan Hipotesis pada Masalah yang Disajikan

Siswa menuliskan masalah yang muncul dalam kasus yang disajikan dalam lembar kerja, kemudian mencari informasi dalam ilustrasi, dan membuat hipotesisnya. Masalah serta hipotesis dapat berbeda antar kelompok, karena permasalahan yang muncul dalam diskusi setiap kelompok berbeda.

Identifikasi masalah dan hipotesis mengakibatkan siswa berpikir dalam level HOTS, yaitu berpikir kritis dan metakognisi, karena siswa perlu merencanakan, memonitor pemahaman, dan mengevaluasi permasalahan. Schraw \& Robinson (2011: 191) menjelaskan bahwa dalam berpikir metakognisi, siswa melibatkan kontrol aktif terhadap proses kognitif dalam pembelajaran. Selain itu, siswa juga perlu memahami dan mengungkapkan makna dari aturan, situasi, maupun data dari permasalahan yang ada. Hal ini juga sesuai dengan interpretation dalam berpikir kritis yang diungkapkan oleh Facione (2011).

Pada tahap penilaian hasil pembelajaran, hasil TKLM berdistribusi normal dan homogen. Taraf signifikan atau $\alpha$ yang digunakan adalah 0,05. Proporsi ketuntasan yang diperoleh adalah $78,13 \%$, dengan nilai $Z_{\text {hitung }}$ adalah 0,40825 dan $Z_{\frac{1}{2}}(1-\alpha)$ adalah 1,96, sehingga $\quad-Z_{\frac{1}{2}(1-\alpha)}<z_{\text {hitung }}<Z_{\frac{1}{2}(1-\alpha)}$, yang berarti proporsi ketuntasan siswa adalah 75\%. Sedangkan proporsi ketuntasan kelas kontrol adalah 38,24\%. Berdasarkan hasil analisis uji banding proporsi, nilai $Z_{\text {hitung adalah } 3,277 \text { dan nilai } Z_{(0,5-a)}}$ adalah 1,64 , sehingga $Z_{\text {hitung }} \geq Z_{(0,5-a)}$, yang berarti proporsi ketuntasan siswa kelas yang memperoleh materi pembelajaran menggunakan Discovery Learning-HOTS lebih dari proporsi ketuntasan siswa kelas yang memperoleh materi pembelajaran menggunakan pembelajaran Discovery Learning.

Rata-rata nilai siswa adalah 79,58 , dengan nilai thitung adalah 1,7192, dan $t_{1-\mathrm{a}) \text {,dk }}$ adalah 1,694, sehingga $t_{\text {hitung }}>$ $t_{(1-\mathrm{a}), \mathrm{dk}}$, yang berarti rata-rata literasi matematika siswa dari kelas yang memperoleh materi pembelajaran menggunakan Discovery LearningHOTS lebih dari 76. Rata-rata kelas kontrol adalah 72,69. Berdasarkan hasil analisis uji banding rata-rata, nilai $t_{\text {hitung }}$ adalah 2,1449 dan nilai $t_{1-}$ a),dk adalah 1,669 , sehingga thitung $>t_{(1-}$ a),dk, yang berarti rata-rata literasi matematika siswa kelas yang memperoleh materi pembelajaran menggunakan pembelajaran Discovery Learning-HOTS lebih dari kelas yang memperoleh materi pembelajaran menggunakan Discovery Learning. Oleh karena itu, tahap penilaian pembelajaran Discovery LearningHOTS dikatakan berkualitas.

Berdasarkan perhitungan uji gain ternormalisasi, self-efficacy siswa 
meningkat dengan kriteria rendah, yaitu 43,75\% siswa mengalami peningkatan self-efficacy dengan kategori sedang, dan 53,125\% siswa mengalami peningkatan self-efficacy dengan kategori rendah.

TKLM per level self-efficacy menunjukkan rata-rata nilai yang diperoleh siswa dengan self-efficacy tinggi adalah 93,75, siswa dengan self-efficacy sedang adalah 81,41, dan siswa dengan self-efficacy rendah adalah 63,39.

Berdasarkan uji regresi, diperoleh hasil bahwa self-efficacy memiliki pengaruh positif terhadap literasi matematika siswa meskipun tidak dominan, yaitu $34,6 \%$, dan terdapat $65,4 \%$ oleh faktor lain seperti faktor sosial, kondisi psikologi siswa, maupun kondisi fisik siswa saat penilaian literasi dilaksanakan.

Pada aspek communication, siswa dengan self-efficacy tinggi mampu menyatakan informasi yang diketahui, masalah yang ditanyakan, serta ide penyelesaian masalah dengan benar dan lengkap.

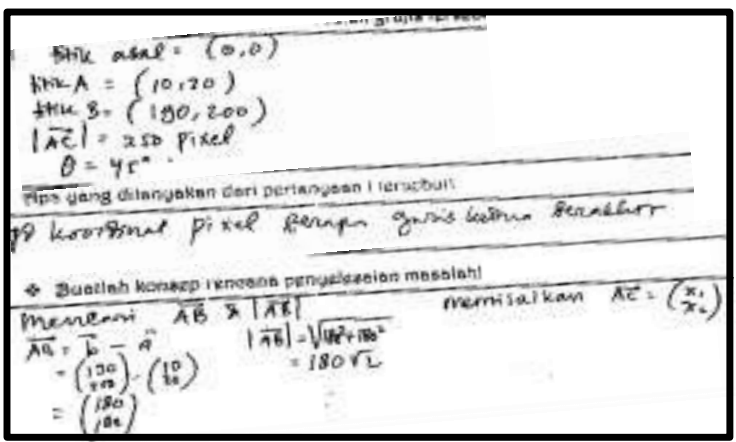

Gambar 2 Contoh Pekerjaan Siswa Self-Efficacy Tinggi Aspek Communication

Hasil itu menunjukkan bahwa siswa dapat menyatakan informasi yang diketahui, masalah yang ditanyakan, serta ide konsep penyelesaian masalah dengan benar, tepat, dan lengkap.

Siswa dengan self-efficacy sedang juga sudah memiliki communication yang cukup baik, meskipun siswa belum mampu menyelesaikan masalah sesuai konsepnya. Namun untuk siswa dengan self-efficacy rendah, siswa hanya mampu mengomunikasikan sedikit gagasan konsep penyelesaian sesuai permasalahan yang disajikan, meskipun gagasan tersebut tidak tepat.

Pada aspek mathematising, siswa dengan self-efficacy tinggi dapat menyebutkan informasi yang diketahui dan ditanyakan secara benar dan sangat lengkap, dan membuat bentuk matematika dari kasus yang diajukan dengan benar dan tepat. Siswa dengan self-efficacy sedang juga telah dapat mengubah permasalahan dalam kasus soal ke bentuk matematika dengan benar, serta dengan pendefinisian yang tepat, namun kurang lengkap.

$$
\begin{aligned}
& \theta=\log , 5^{\circ} \\
& \vec{u}^{2}=3 i+4 j \\
& \vec{v}^{7}=h i+4 j
\end{aligned}
$$

Gambar 3 Contoh Pekerjaan Siswa Self-Efficacy Sedang Aspek Mathematising

Hasil tersebut menunjukkan bahwa siswa dapat membuat bentuk matematika dari kasus yang diajukan dengan benar, namun kurang lengkap karena tidak dijelaskan. Siswa dengan self-efficacy rendah juga belum dapat menguasai aspek mathematising, karena belum mampu membuat model matematika yang tepat dan lengkap.

Pada aspek reasoning and argument, siswa dengan self-efficacy tinggi dapat menyelesaikan masalah sesuai konsep yang telah direncanakan secara benar dan lengkap, kemudian membuat kesimpulan akhir dan menjelaskan secara rinci mengenai alasan atau dasar kesimpulan dari penyelesaian yang dibuatnya. 
Siswa dengan self-efficacy sedang dapat memberikan kesimpulan yang tepat serta alasan atau cara pengerjaan yang benar dan lengkap.

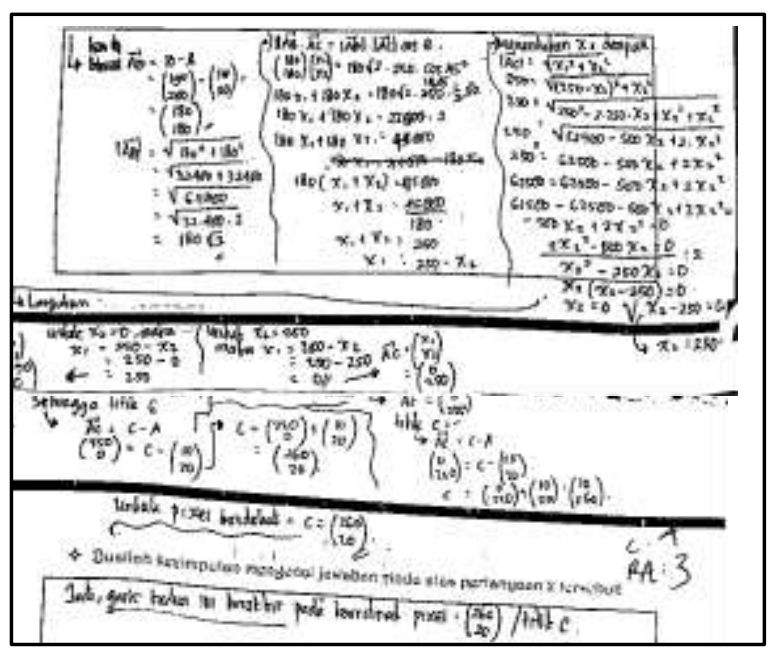

Gambar 4 Contoh Pekerjaan Siswa Self-Efficacy Sedang Aspek Reasoning and Argument

Hasil pekerjaan di atas menunjukkan bahwa siswa mampu menyelesaikan permasalahan disertai dengan kesimpulan. Namun pada analisis akhir, siswa masih kurang tepat dalam menentukan vektor yang digunakan akibat pengukuran arah sudut yang tidak sesuai. Siswa dengan self-efficacy rendah juga belum dapat menguasai aspek reasoning and argument, karena siswa hanya menuliskan kesimpulan dari setengah jawabannya saja.

Pada aspek devising strategies for solving problems, siswa dengan selfefficacy tinggi dan sedang mampu membuat penyelesaian dari strategi yang telah dibuat terlebih dahulu sampai menemukan penyelesaian yang benar. Siswa dengan self-efficacy rendah juga mampu memberikan langkah penyelesaian yang benar namun dengan hasil perhitungan yang salah dan tidak menginterpretasikan strategi yang digunakan untuk menyelesaikan masalah.

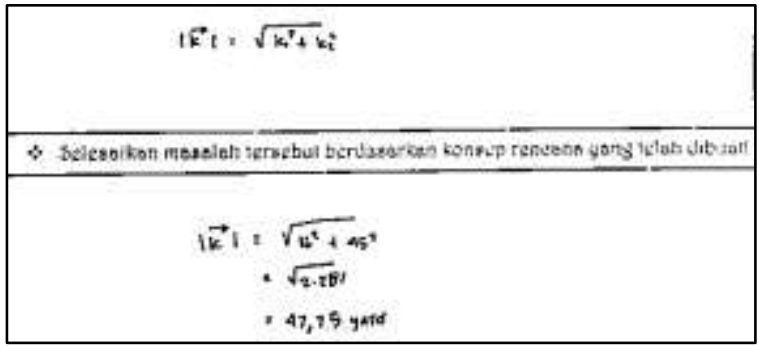

Gambar 5 Contoh Pekerjaan Siswa Self-Efficacy Rendah Aspek Devising Strategies for Solving Problems

Hasil pekerjaan siswa di atas menunjukkan bahwa siswa sudah dapat membuat konsep meskipun tidak menginterpretasikannya, serta membuat penyelesaian masalah.

Pada aspek representation, siswa dengan self-efficacy tinggi dan sedang mampu menyajikan kembali permasalahan dengan membuat gambar dan menginterpretasikannya dengan baik, meskipun masih terdapat sedikit kekeliruan dalam penyelesaiannya.

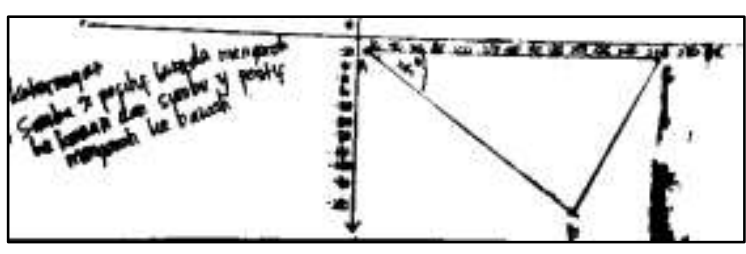

Gambar 6 Contoh Pekerjaan Siswa Self-Efficacy Sedang Aspek Representation

Hasil tersebut menunjukkan bahwa siswa dengan self-efficacy sedang mampu menyajikan kembali permasalahan dengan membuat gambar disertai keterangan, namun kurang sesuai dengan kasus yang disajikan dalam hal arah sudut. Sedangkan siswa dengan self-efficacy rendah belum dapat menguasai aspek representation, karena siswa belum mampu membuat representasi kasus dalam gambar.

Pada aspek using symbolic, formal and technical language and operation, siswa dengan self-efficacy tinggi dan sedang mampu menggunakan simbol, 
bahasa formal dan teknik, dan operasi untuk merumuskan, memecahkan atau menafsirkan masalah dengan baik, meskipun terdapat ketidakkonsistenan dalam penulisan simbol.

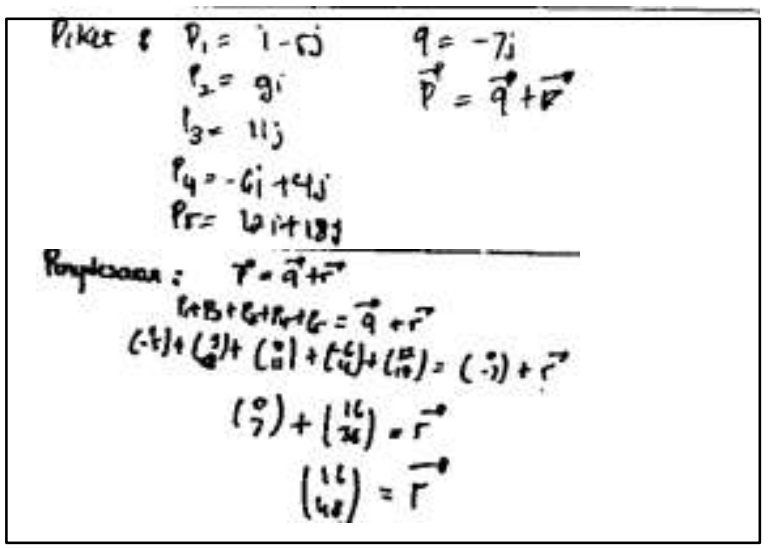

Gambar 7 Contoh Hasil Pekerjaan Siswa Self-Efficacy Tinggi Aspek Using Symbolic, Formal Technical Language and Operation

Hasil pekerjaan di atas menunjukkan bahwa siswa sudah mampu menyelesaikan masalah dengan simbol-simbol serta operasi yang benar. Akan tetapi, siswa tersebut beberapa kali melakukan kesalahan penulisan lambang vektor yang seharusnya memiliki tanda panah di atas variabel, atau dituliskan tebal untuk memberi perbedaan dengan penulisan skalar.

Siswa dengan self-efficacy rendah juga belum mampu menguasai aspek using symbolic, formal and technical language and operation, karena terdapat banyak ketidaktelitian siswa terhadap simbol vektor, serta kurang mampu dalam membuat, memahami, serta menjelaskan simbol matematika yang sesuai dengan kasus soal.

Pada aspek using mathematics tools, siswa siswa dengan self-efficacy tinggi dan sedang dapat menggunakan alatalat matematika misalnya alat ukur, penggaris, dan sebagainya dengan baik, skala tepat, dan rapi.

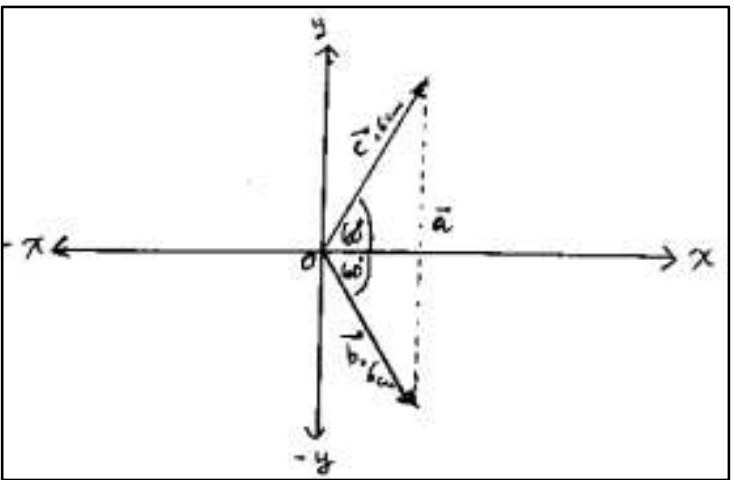

Gambar 8 Contoh Hasil Pekerjaan Siswa Self-Efficacy Tinggi Aspek Using Mathematics Tools

Hasil tersebut menunjukkan bahwa siswa dapat menggunakan alat-alat matematika untuk menggambar vektor dengan penggaris, busur derajat, dan rapi meskipun belum melukiskan skala yang digunakan. Adapun siswa dengan self-efficacy rendah kurang cakap dalam menggunakan alat-alat matematika misalnya pengukuran, penggaris, dan sebagainya, karena terdapat ilustrasi yang tidak sesuai keterangan pada gambar, kurang rapi, dan tidak maksimal.

Hasil TKLM serta wawancara terhadap subjek memberikan hasil bahwa selfefficacy linier dengan literasi matematika. Siswa dengan selfefficacy tinggi memiliki literasi matematika yang sangat baik, siswa dengan self-efficacy sedang memiliki literasi matematika yang cukup, serta siswa yang memiliki self-efficacy rendah ini belum mampu menguasai aspek literasi matematika dengan benar, tepat, dan lengkap. Hal ini sesuai dengan pernyataan dari Zimmerman (2000: 84) bahwa penilaian self-efficacy dapat mengarahkan penaksiran siswa sebelum melakukan suatu aktivitas.

Literasi matematika yang ditunjukkan oleh siswa dengan self-efficacy tinggi didasari oleh keinginan siswa yang sangat kuat untuk menguasai matematika dengan baik. Schunk dan Pajares (2001: 14) menyatakan bahwa 
siswa yang memiliki efficacy tinggi akan menyelesaikan tugas pembelajaran dengan baik, berpartisipasi dalam pembelajaran dengan lebih siap, bekerja keras, bertahan lebih lama saat mereka menemui kesulitan, serta mampu memperoleh prestasi yang lebih tinggi. Ahmad dan Safaria (2013: 28) juga menyebutkan bahwa siswa dengan self-efficacy tinggi memiliki tujuan yang lebih tinggi daripada siswa dengan self-efficacy rendah. Siswa juga percaya bahwa mereka dapat menyelesaikan berbagai persoalan dan mendapatkan nilai yang sangat baik pada tes matematika.

Literasi matematika yang ditunjukkan oleh siswa dengan self-efficacy sedang didasari oleh keyakinan siswa untuk menguasai mata pelajaran matematika dengan baik, namun tidak kuat. Siswa berusaha untuk selalu berkomunikasi dengan teman sebaya untuk mencari solusi terbaik dari masalah matematika yang dihadapi, meskipun terkadang mereka menghindar melaksanakan tugas sekolah. Mereka cukup antusias mengikuti pelajaran matematika di sekolah, cukup mampu memotivasi diri untuk belajar matematika, namun sering merasa gugup sehingga tidak dapat konsentrasi apabila menemui kesulitan dalam menyelesaikan suatu permasalahan matematika.

Siswa yang memiliki self-efficacy rendah memiliki karakter cenderung lebih mudah menyerah dalam menghadapi masalah yang tergolong sulit. Dalam melaksanakan tugas sekolah, terkadang siswa berkeinginan untuk mengerjakannya, terkadang pula menghindarinya, dan merasa putus asa. Menurut Schunk $\&$ Pajares (2001: 14), siswa dengan efficacy rendah cenderung memilih tugas pelajaran dan aktivitas yang berkaitan dengan materi yang mereka sukai dan terasa mudah bagi mereka.

\section{Simpulan}

Pembelajaran Discovery LearningHOTS terhadap literasi matematika siswa adalah berkualitas. Hal ini ditunjukkan dengan penilaian pada tiga tahap pembelajaran, yaitu tahap perencanaan pembelajaran, pelaksanaan pembelajaran, dan penilaian hasil pembelajaran.

Literasi matematika yang dianalisis berdasarkan self-efficacy memberikan kesimpulan bahwa siswa yang memiliki self-efficacy tinggi mampu menguasai empat aspek proses literasi matematika dengan sangat baik, yaitu communication, mathematising, reasoning and argument, devising strategies for solving problems, sedangkan tiga aspek lainnya masih ada sedikit kesalahan. Siswa yang memiliki self-efficacy sedang mampu memiliki satu aspek proses literasi matematika dengan sangat baik dan maksimal, yaitu devising strategies for solving problems, serta enam aspek literasi matematika lainnya dapat dikuasai dengan baik meskipun kurang maksimal. Sedangkan siswa yang memiliki self-efficacy rendah belum mampu menguasai aspek literasi matematika dengan maksimal. Dari tujuh aspek proses literasi matematika, lima aspek dapat dikuasai siswa dengan baik walaupun tidak maksimal, dan untuk dua aspek lainnya, yaitu communication dan using symbolic, formal and technical language and operation, siswa cenderung belum mampu.

Self-efficacy berpengaruh positif terhadap literasi matematika siswa. Oleh karena itu, penilaian dan pengembangan self-efficacy cukup membantu saat guru ingin mengetahui dan menumbuhkan literasi matematika siswa di kelas. 


\section{Daftar Pustaka}

Ahmad, A. \& Safaria, T. (2013). Effects on Self-Efficacy on Students' Academic Performance. Journal of Educational, Health and Community Psyvhology, 2 (1).

Bandura, A. (1994). Self-efficacy. Dalam V.S.Ramachaudran (Ed.). Encyclopedia of human behavior, 4, 71-81. New York: Academic Press.

Facione, P. A. (2011). Critical Thinking: What It Is and Why It Counts. Milbrae: Measured Reasons and The California Academic Press.

Junaedi, I. \& Asikin, M. (2012). Pengembangan Pembelajaran Matematika Humanistik Untuk Meningkatkan Kemahiran Matematis. Unnes Journal of Mathematics Education Research, Vol. 1 No 2.

King, FJ., Goodson, L., \& Rohani, F. (1998). Higher Order Thinking Skillss: Definitions, Teaching Strategies, Assessment. http://www.cala.fsu.edu/files/higher order thinking skillss.pdf. Diakses pada 5 Oktober 2017, pukul 20.05.

OECD. (2016). PISA 2015 Results (Volume I): Excellence and Equity in Education. PISA. Paris: OECD Publishing. http://dx.doi.org/10.1787/9789264266490en. Diakses pada 3 Oktober 2017, pada 20.15.

Ozgen, K., \& Bindak, R. (2011). Determination of Self-Efficacy Beliefs of High School Students Towards Math Literacy. Educational Science: Theory \& Practice, 11 (2), pp 1085-1089.

Rajendran, N. S. (2008). Teaching \& Acquiring Higher Order Thinking Skills Theory $\&$ Practice. Kuala Lumpur: Penerbit University Pendidikan Sultan Idris.

Retnowati, E., \& Aqiilah. (2017). Efektivitas Strategi Pengelompokan Berpasangan Dalam Pembelajaran Matematika Model Core. Jurnal Ilmiah Pendidikan, (Juni 2018), No.2.

Schraw, G. \& Robinson, D. (2011). Assesment of Higher Order Thinking Skills. Carlotte: IAP.

Schunk, D. H. \& Pajares, F. (2001). The Development of Academic Self-Efficacy. San Diego: Academic Press.

Waluya, S.B. (2012). Peran Matematika dan Pendidikan Matematika dalam Membangun Karakter Bangsa. Makalah pada Seminar Nasional Matematika dan Pendidikan Matematika. 10 November 2012. Yogyakarta: Jurusan Pendidikan Matematika FMIPA UNY.

Zimmerman, B.J. (2000). Self-Efficacy: An Essential Motive to Learn. Contemporary Educational Psychology, 25, 82-91. 